\title{
Metformin therapy in pregnancy
}

\author{
Joanna Krupej-Kędzierska ${ }^{1,2}$, Edyta Cichocka' ${ }^{1}$ Leszek Kędzierski , Bogusław Okopieñ ${ }^{2}$, \\ Janusz Gumprecht ${ }^{1}$
}

${ }^{1}$ Department of Internal Medicine, Diabetology and Nephrology, Faculty of Medical Sciences in Zabrze, Medical University of Silesia, Katowice, Poland

${ }^{2}$ Department of Internal Medicine and Clinical Pharmacology, Medical University of Silesia, Katowice, Poland

${ }^{3}$ Department of Internal Medicine and Metabolic Diseases, Medical University of Silesia, Katowice, Poland

\begin{abstract}
Gestational diabetes mellitus (GDM), i.e. a carbohydrate metabolism disorder at pregnancy, is one of the most common metabolic complications that occur during this period. Pancreatic $\beta$-cell dysfunction and insulin resistance during pregnancy are considered the main causes of the condition. It is currently estimated that GDM is confirmed in 1-25\% of patients. Diagnosis and appropriate management allow to reduce the risk of complications in newborns and the perinatal mortality rate and also improve the prognosis for mother and offspring. Metformin is taken by many patients before pregnancy due to both previously diagnosed type 2 diabetes and in the treatment of prediabetes, obesity and polycystic ovary syndrome (PCOS) as part of therapy for insulin resistance. The use of metformin in pregnancy has been controversial for many years, particularly in terms of the safety of continuation of drug therapy. Available scientific data indicate both benefits and possible drug-related adverse effects in offspring of metformin-treated patients. This problem is related not only to patients with type 2 diabetes, but also to those with PCOS who are at increased risk of miscarriage, preterm delivery and the diagnosis of GDM in subsequent stages of pregnancy. Conclusive and uniform recommendations for the use of metformin at each stage of pregnancy have not been established yet due to the doubts about the mechanisms of action of the drug, particularly at the cellular level. This review paper presents the current state of knowledge on the use of metformin during pregnancy. (Endokrynol Pol 2020; 71 (2): 184-189)

Key words: metformin; pregnancy; gestational diabetes
\end{abstract}

\section{Introduction}

Gestational diabetes mellitus (GDM), i.e. a carbohydrate metabolism disorder at pregnancy, is one of the most common metabolic complications that occur during this period [1]. This type of hyperglycemia is first detected in pregnancy in patients with no previous history of carbohydrate metabolism disorders. Pancreatic $\beta$-cell dysfunction and insulin resistance during pregnancy are considered the main causes of the condition. A predisposition to this disorder already exists before pregnancy and hormonal changes and pregnancy-related weight gain lead to the manifestation of this condition $[2,3]$. Environmental factors are also involved, one of the major being the obesity epidemic resulting from harmful eating habits as well as adverse changes in lifestyle observed throughout the entire world [1].

It is estimated that approximately $1 \%$ of patients have diabetes at the time of becoming pregnant. In turn, GDM is observed in 1-25\% of patients depending on the country of origin, which is associated with different diagnostic criteria and the impact of ethnic factors [4-7]. Diagnosis of GDM and appropriate management allow to reduce the risk of complications in newborns and the perinatal mortality rate as well as improve the prognosis for mother and offspring [8]. Maternal GDM is considered a strong predictor of metabolic disorders in a child, both in childhood and adulthood.

Currently, in accordance with the guidelines of the World Health Organization (2013) adopted in Poland, hyperglycemia in pregnancy is divided into two categories, i.e. diabetes in pregnancy (with the onset in pregnancy) defined as a disorder that meets the general criteria for the diagnosis of diabetes and GDM which develops most often in the second or third trimester of pregnancy and meets the specific criteria for the period of pregnancy. There is also a group of patients who at the time of pregnancy confirmation are already diagnosed with type 2 diabetes and are given oral drugs (mostly metformin).

Due to the multitude of clinical situations, the use of metformin in pregnancy has been controversial for many years. This drug is taken by many patients before pregnancy due to both previously diagnosed type 2 diabetes and in the treatment of prediabetes, obesity and polycystic ovary syndrome (PCOS) as part of therapy for insulin resistance [9]. In addition, metformin can be used in many countries as one of the therapeutic op-

Edyta Cichocka MD, PhD, Department of Internal Medicine, Diabetology and Nephrology in Zabrze, ul. 3 Maja 13/15, 41-800 Zabrze,

Poland, tel: (+48) 530032 206; e-mail: ecichocka@sum.edu.pl 
tions for GDM, which is often determined by economic factors. Therefore, the following questions should be posed: Is further therapy with metformin safe in patients in whom it was used during the periconceptional period? And if so, how long can it be used safely so as not to expose the developing fetus to its potentially adverse effects? These questions are related not only to patients with type 2 diabetes, but also to those with PCOS who are at increased risk of miscarriage, premature delivery and the diagnosis of GDM in subsequent stages of pregnancy [6].

Scientific data from clinical trials and surveys conducted in patients using metformin during pregnancy indicate higher therapy-related satisfaction, lower stress intensity connected with the diagnosis and in many cases as good glycemic control as in the groups of patients using insulin therapy as the only therapeutic option [10]. However, it should be borne in mind that metformin should not be considered a therapeutic option in the group of patients suspected of placental insufficiency, arterial hypertension, preeclampsia or intrauterine growth restriction [11]. In addition, the analysis of scientific data shows that obese patients with higher fasting glucose will require insulin therapy. Therefore they belong to the group of patients that will potentially benefit less from using this drug [12]. Therefore, in many cases, as pregnancy progresses, the use of metformin is not the definite solution and insulin therapy must be introduced as there is a risk that patients will have poorer glycemic control compared to patients using insulin as the first-line treatment [11].

Another important aspect of oral metformin therapy (that is either continued or introduced) is the period of pregnancy when the use of the drug is completely safe for the fetus. The first trimester of pregnancy, which is a period of intense organogenesis, is of particular concern. In the countries where this drug is approved in pregnancy, it should be used in the second and third trimesters when it is considered safer as there is still insufficient data on its potentially teratogenic effect in the first trimester [4].

Poor glycemic control is associated with serious perinatal complications, which include birth weight large for gestational age, premature delivery, caesarean delivery, congenital anomalies, preeclampsia, neonatal hypoglycemia and increased risk of miscarriage in the early stages of pregnancy [5]. Therefore, the following are of crucial importance: preparation for pregnancy during the preconception period, reaching the recommended criteria for glycemic control in patients with previously diagnosed diabetes, normalization of body weight and identification of women at higher risk for developing GDM, both at the beginning of pregnancy and in the second and third trimesters $[5,13,14]$.

\section{Management of GDM}

In 1970, Coetzee and Jackson were the first who described the use of metformin in pregnancy [15]. Since then, many authors have emphasized significant benefits of oral pharmacotherapy during this period which are related to better patient compliance, more rapid achievement of glycemic control and the lower cost of drug treatment. The use of oral therapy eliminates the fear of insulin injections, hypoglycemia and uncontrolled weight gain during pregnancy $[1,5]$.

In 2019, Kumar et al. presented the results of the "Metformin first" protocol, which included patients with GDM. Their subjects were informed of two options and were provided with the information on potential therapy-related adverse effects. It was a prospective patient survey, including patients who were pregnant in 2015 and 2016. Based on the collected data, no increased risk was found for congenital anomalies or perinatal complications for the mother or the fetus. On the other hand, those authors reported satisfactory glycemic control, effectiveness of treatment and higher patient satisfaction with treatment in the group of patients on metformin [16].

The aims of GDM treatment are to prevent fetal macrosomia and its sequelae, perinatal complications and to reduce the risk of developing cardiovascular complications in children of mothers with GDM in the future. In 2019 Tarry-Adkins et al. conducted a meta-analysis of studies obtained from the medical database (PubMed). The following were excluded: studies which included participants with pre-existing diabetes, multiple pregnancies or those in which the group size was fewer than 50 women. The analysis showed that during pregnancy the fetuses of metformin-treated mothers had lower body weight, and neonates had lower birth weight. However, in later life those children have higher average body weight than the children of mothers treated with insulin during pregnancy, which is a risk factor for cardiovascular disease in adult life [17]. In addition, the study demonstrated that in children of metformin-treated mothers higher abdominal and visceral fat volumes and higher BMI with no differences in the body length were observed at the age of 2 [17]. In turn, at the age of 5, higher BMI was reported, which could be due to increased storage of abdominal fat $[17,18]$.

\section{Review of the selected current studies and meta-analyses on the use of metformin in pregnancy}

Metformin acts on peripheral tissues, increasing their sensitivity to insulin and it also reduces hepatic gluconeogenesis. It also exerts other properties, which include modulation of gene expression, anti-tumor 
effects and anti-inflammatory action by inhibiting the production of proinflammatory cytokines and reducing the differentiation of monocytes into macrophages [6]. Its action is associated with a decrease in electron transport in the liver mitochondria, leading to reduced gluconeogenesis and lipogenesis.

Unlike insulin, metformin passes across the placental barrier [19]. The fetal blood concentration of metformin is comparable to that in the maternal blood. This may result in effects expressed at the cellular level, thereby altering cell metabolism in the early stages of growth and differentiation [6]. This impact is related to both fetal and placental tissues. Due to the limited amount of clinical data, such effects are difficult to predict, also in long-term follow-up [6]. The organic cation transporter 3 (OCT-3), which is characteristic of pregnancy, plays a role in the transplacental transport of metformin [6]. It depends on the pregnancy stage and the placental structure and efficiency. There is also a potential for drug accumulation within the placental tissues, and therefore its impact on cell metabolism is more difficult to predict and the potential effect may be prolonged over time [6].

The release of metformin into the fetal blood in the early stages of embryogenesis may potentially have a teratogenic effect. However, it has not been confirmed by studies. At the early stages of pregnancy, the mechanisms of aerobic respiration do not play such a crucial role in the processes of cell growth and differentiation due to a small number of mitochondria and the dominant anaerobic metabolism during this period. This relationship changes in the subsequent stages of pregnancy when the mechanisms of aerobic respiration in mitochondria are prevalent at the cellular level and then they can be blocked by metformin. In addition, the drug inhibits the mechanisms of proliferation and protein synthesis and also enhances apoptosis in cells by activating the AMP-kinase. It is also suggested that metformin may exert epigenetic effect, which may cause metabolic effects in later life [11].

In 2019, the study by Bao et al., which considered the registry from 11 European countries, did not show an increased risk of congenital anomalies in children whose mothers used metformin in the first trimester of pregnancy. However, apart from a potential teratogenic effect, there is also a possible impact of using this drug by a pregnant mother on later life of the child [5].

A meta-analysis of randomized control studies that were collected based on medical databases (PubMed, Embase, Cochrane Library) considered the sequelae of maternal metformin treatment during pregnancy and the impact on the fetus and children in later life. Pregnant women with prepregnancy diabetes were excluded from the study. All the patients were treated with metformin, metformin combined with insulin and insulin alone. Overall, 24 studies were analyzed in the meta-analysis, including 17 randomized studies. The assessed neonatal outcomes included birth weight, macrosomia, neonatal hypoglycemia, small for gestational age (SGA) newborns, need for intensive care, Apgar score $(<7)$ at $5 \mathrm{~min}$, hyperbilirubinemia, respiratory distress syndrome, congenital anomalies and $\mathrm{pH}$ of the umbilical cord. The assessed maternal outcomes included gestational age at delivery, pregnancy-induced hypertension, the number of cesarean deliveries, maternal weight gain and glycemic control $\left(\mathrm{HbA}_{1 \mathrm{c}} \%\right)$ [5]. $847 \mathrm{GDM}$ patients were enrolled in the analysis of pregnancy duration and maternal age at delivery. This part of the analysis showed that metformin can shorten the pregnancy and induce premature delivery [5]. There were no differences in the percentage of cesarean deliveries. However, total maternal weight gain during pregnancy in the group of patients on metformin was lower compared to patients on insulin [5].

In terms of neonates, it was found that their birth weight was lower in the group of metformin-treated women. Moreover, it was demonstrated that oral treatment slightly lowered the risk of fetal macrosomia. In addition, children of metformin-treated mothers had a lower risk of post-delivery hypoglycemia and a lower number of admissions to the intensive care unit was reported in this group [5]. The most important factor that influenced the occurrence of perinatal complications was poor glycemic control in the pre-pregnancy period and in the first trimester of pregnancy.

The assessment of metformin use in pregnant women in later life of offspring was based on five randomized clinical trials. Rowan et al. showed that there was no difference between the groups of patients on metformin and on insulin in terms of the presence of centrally deposited fat. However, children of metformin-treated mothers had higher accumulation of subcutaneous fat at 2 years of age, which shows that metformin promoted subcutaneous fat deposition and visceral tissue but to a lesser extent $[20,21]$. The follow-up of these subjects at 12 and 18 months of age showed that they had significantly higher body weight. At 18 months of age, they were taller compared to children of insulin-treated mothers [12]. No differences were observed in terms of motor, linguistic, or social development [22]. A similar observation was made by Tertti et al., however, their study showed that children of metformin-treated mothers were characterized by poorer linguistic skills $[23,24]$. Further observation by Rowan et al. (2018) was related to children aged 7-9 years and showed that the subjects exposed to metformin were heavier than those of insulin-treated mothers [25]. 
In another meta-analysis, Bao et al. emphasized the benefits of oral therapy resulting from a significant reduction in postprandial glucose, earlier achievement of therapeutic goals and lower weight gain in metformin-treated groups. The baseline body weight and the change in the lifestyle of patients are also of importance. On the other hand, in terms of neonatal complications, those authors stressed reduced risk of neonatal hypoglycemia and, as a result, neonatal brain injury [5].

In 2015, Ainudi et al. conducted a study on a group of women from Pakistan and South Asia related to the use of metformin as monotherapy in pregnancy, metformin combined with insulin, or insulin alone. The study showed that patients on metformin and metformin with insulin presented with lower weight gain compared to patients on insulin. There were also more normal vaginal deliveries in metformin-treated patients than in the insulin group [8].

The use of metformin in GDM was also assessed in the Metformin in Gestational (MiG) Diabetes Trial, which involved 751 women who were divided into two groups (i.e. metformin and insulin). In the metformin group, $46.3 \%$ of patients also required supplemental insulin treatment to improve glycemic control. In the metformin group, more preterm deliveries were reported with a lower risk of neonatal hypoglycemia compared to insulin-treated patients. The MiG TOFU study was the continuation of the above follow-up. Children of mothers participating in the MiG study underwent long-term assessment (at 2, 4 and 9 years of age). At 2 years of age, those children had larger mid-upper arm circumferences, subscapular and bicep skinfolds compared to those children whose mothers used insulin. The assessment at 9 years showed that metformin-exposed offspring had higher BMI, greater subscapular and bicep skinfolds and larger (upper)-arm and waist circumferences [12, 25].

The available literature shows that the effect of metformin on fetal tissues in the first trimester of pregnancy may be insignificant due to the limited number of OCTs at the beginning of pregnancy in fetal tissues. However, the amount of data on the use of this drug in the first trimester of pregnancy is limited [26]. During this period of fetal development, the processes of aerobic respiration in mitochondria play a less significant role, and the importance of such respiration becomes more crucial in the second and third trimesters of pregnancy $[6,10]$. According to some hypotheses, metformin can affect placental tissues to a greater extent, thus modifying the transport of nutrients necessary for growth and differentiation, and affecting placental development and thereby indirectly modulating fetal growth. The available studies are mostly related to patients who used the drug before pregnancy as therapy supporting the treatment of infertility in PCOS and at the same time the drug was not discontinued at the beginning of pregnancy [10].

Citrin et al. assessed the impact of metformin on the fetus in the first trimester of pregnancy. Patients with type 2 diabetes mellitus and PCOS who were treated with metformin for at least the first trimester of pregnancy were enrolled in the study. The control group consisted of patients treated with insulin from the beginning of pregnancy. Patients from the metformin group were older, had higher BMI and a higher number of previous miscarriages [26]. Those authors did not demonstrate adverse effects of the drug on the risk of congenital anomalies or perinatal complications. The abnormalities found in the study were mainly associated with poor glycemic control in all study groups [26]. Women with PCOS are at greater risk of perinatal complications such as miscarriage, preeclampsia or GDM [27].

In 1991, Piacquadio et al. reported congenital anomalies in children whose mothers had been diagnosed with type 2 diabetes and had received metformin before pregnancy and continued therapy in the first trimester. However, the size of groups was small. In addition, the probable large number of cases of untreated pre-pregnancy diabetes and poor glycemic control in this group of patients could have an impact on the results [10, 28-30]. In 2013, Begum et al. found no congenital anomalies in offspring of patients with PCOS who used metformin at the beginning of pregnancy [31].

A relatively small size of study and control groups constitute a significant limitation of the above studies. In addition, metformin was discontinued after pregnancy or before the end of the first trimester in many studies. Therefore the obtained results may not be conclusive.

In 2010, the results of the prospective randomized control study (PregMet) on patients with PCOS using metformin revealed that head circumferences of fetuses (at gestational week 32) and neonates at birth were larger. However, this finding was related only to children born to women who had been obese or overweight already in the pre-pregnancy period [32]. Moreover, the child's head circumference was a beneficial factor that improved cognitive functions and the prognosis for cardiovascular disease [32]. Children of mothers without overweight or obesity had lower length and body weight after delivery than children in the control group [32]. It was also demonstrated that children of patients with PCOS who received placebo had lower length with the typical average body weight, which may indicate the inhibitory effect of PCOS on growth [32]. Further follow-up showed that children 
at the age of 4 had higher BMI and a greater tendency to overweight and obesity compared to children from the control groups [6,32].

Of note, the use of metformin before and throughout pregnancy in women with PCOS may be a protective factor, particularly against late perinatal complications such as miscarriage after 13 weeks of pregnancy and premature delivery. In 2019, the results of the PregMet2 study were reported. The first group comprised patients with PCOS who used metformin (or placebo) due to perinatal causes in the periconceptional period and then from the beginning of pregnancy. The second group consisted of patients in whom drug treatment was not introduced. The study showed that lower weight gain was found in the metformin-treated group compared to the placebo group. No differences in terms of neonatal body weight were observed. However, a larger head circumference was reported in metformin-exposed children, which is in line to the findings in PregMet. No statistically significant difference was found in the occurrence of preterm delivery or late miscarriages (after gestational week 13). Furthermore, the effect of metformin on the development of GDM or subsequent therapeutic interventions in these patients was not confirmed [33, 34]. Despite several meta-analyses on this subject, no clear results have been obtained in terms of protective effects of metformin against miscarriage. Additionally, meta-analyses did not confirm that discontinuation of the drug at the beginning of pregnancy increased the risk of miscarriage [6].

Recently there have been attempts to use metformin to prevent GDM in patients with PCOS and pre-pregnancy obesity. In 2018, Doi et al. conducted a meta-analysis of studies from 2012 to 2018 which did not confirm the preventive effect of metformin in those groups [2].

A significant disadvantage of clinical studies on the use of metformin in pregnancy is related to the fact that small groups of patients were enrolled in those studies and pharmacological interventions were often interrupted in the subsequent months of pregnancy, which significantly limits observations and does not allow to draw definitive conclusions. In many cases patients were diagnosed with pre-pregnancy type 2 diabetes and glycemic control was poor. Therefore congenital anomalies could be due to the exposure to hyperglycemia rather than the result of the use of metformin in the early stages of pregnancy [10].

\section{Conclusion}

Many questions remain unanswered despite a number of studies and meta-analyses on metformin in pregnancy, in PCOS with insulin resistance, and in the continuation of therapy of type 2 diabetes. In this group of patients, no conclusive or uniform recommendations for the use of metformin at each stage of pregnancy have been established yet due to the doubts about the mechanisms of action of the drug, particularly at the cellular level [25]. Possible long-term sequelae of this drug during pregnancy should be thoroughly analyzed. The above follow-ups were too short and were conducted on too small groups of patients. Of note, studies revealed increased BMI and body weight in early childhood in children of metformin-treated mothers, which may affect the increased cardiovascular risk in childhood and adulthood. It should also be borne in mind that many factors (related to maternal lifestyle, pre-pregnancy body weight and weight increase in pregnancy) are responsible for the well-being of the fetus during pregnancy and the prognosis in later life.

The current guidelines of the Polish Diabetes Association on the treatment of GDM clearly recommend starting insulin therapy if diet and lifestyle modifications are no longer effective and in patients treated with oral antidiabetic drugs before pregnancy. It is supported by the ambiguous state of knowledge regarding the effect of metformin on the metabolic profile and possible modifications at the epigenetic level, which may result in permanent and adverse changes in offspring of women with GDM [14].

\section{Conflict of interest}

None declared.

\section{References}

1. Chiefari E, Arcidiacono B, Foti D, et al. Gestational diabetes mellitus: an updated overview. J Endocrinol Invest. 2017; 40(9): 899-909, doi: 10.1007/s40618-016-0607-5, indexed in Pubmed: 28283913.

2. Doi SAR, Furuya-Kanamori L, Toft E, et al. Metformin in pregnancy to avert gestational diabetes in women at high risk: Meta-analysis of randomized controlled trials. Obes Rev. 2020; 21(1): e12964, doi: 10.1111/obr.12964, indexed in Pubmed: 31667980.

3. McIntyre HD, Catalano P, Zhang C, et al. Gestational diabetes mellitus. Nat Rev Dis Primers. 2019; 5(1): 47, doi: 10.1038/s41572-019-0098-8, indexed in Pubmed: 31296866.

4. Cea-Soriano L, García-Rodríguez LA, Brodovicz KG, et al. Safety of non-insulin glucose-lowering drugs in pregnant women with pre-gestational diabetes: A cohort study. Diabetes Obes Metab. 2018; 20(7): 1642-1651, doi: 10.1111/dom.13275, indexed in Pubmed: 29498473.

5. Bao LX, Shi WT, Han YX. Metformin versus insulin for gestational diabetes: a systematic review and meta-analysis. J Matern Fetal Neonatal Med. 2019 [Epub ahead of print]: 1-13, doi: 10.1080/14767058.2019.1670 804, indexed in Pubmed: 31558075.

6. Gonzalez CD, Alvariñas J, Bagnes MFG, et al. Metformin and Pregnancy Outcomes: Evidence Gaps and Unanswered Questions. Curr Clin Pharmacol. 2019; 14(1): 54-60, doi: 10.2174/157488471466618122415111 6, indexed in Pubmed: 30585549.

7. Tarry-Adkins JL, Aiken CE, Ozanne SE. Neonatal, infant, and childhood growth following metformin versus insulin treatment for gestational diabetes: A systematic review and meta-analysis. PLoS Med. 2019; 16(8): e1002848, doi: 10.1371/journal.pmed.1002848, indexed in Pubmed: 31386659 .

8. Ainuddin JA, Karim N, Zaheer S, et al. Metformin treatment in type 2 diabetes in pregnancy: an active controlled, parallel-group, randomized, open label study in patients with type 2 diabetes in pregnancy. J Diabetes Res. 2015; 2015: 325851, doi: 10.1155/2015/325851, indexed in Pubmed: 25874236. 
9. Milewicz A, Kudła M, Spaczyński RZ, et al. The polycystic ovary syndrome: a position statement from the Polish Society of Endocrinology the Polish Society of Gynaecologists and Obstetricians, and the Polish Society of Gynaecological Endocrinology. Endokrynol Pol. 2018; 69(4), doi: 10.5603/EP.2018.0046, indexed in Pubmed: 30209800.

10. Cassina M, Donà M, Di Gianantonio E, et al. First-trimester exposure to metformin and risk of birth defects: a systematic review and meta-analysis. Hum Reprod Update. 2014; 20(5): 656-669, doi: 10.1093/humupd/dmu022, indexed in Pubmed: 24861556.

11. Barbour LA, Feig DS, Barbour LA, et al. Metformin for Gestational Diabetes Mellitus: Progeny, Perspective, and a Personalized Approach. Diabetes Care. 2019; 42(3): 396-399, doi: 10.2337/dci18-0055, indexed in Pubmed: 30787061.

12. Lindsay RS, Loeken MR. Metformin use in pregnancy: promises and uncertainties. Diabetologia. 2017; 60(9): 1612-1619, doi: 10.1007/s00125-017-4351-y, indexed in Pubmed: 28770325.

13. Standards of Medical Care in Diabetes. Diab Care. 2004; 28(Suppl 1): S4-S36, doi: 10.2337/diacare.28.suppl_1.s4, indexed in Pubmed: 15618112

14. PTD Z. Zalecenia PTD. 2017 Guidelines on the management of diabetic patients. A position of Diabetes Poland. Clin Diab. 2017; 6(A): 1-80, doi: $10.5603 / \mathrm{dk} .2017 .0001$.

15. Romero R, Erez O, Hüttemann M, et al. Metformin, the aspirin of the 21st century: its role in gestational diabetes mellitus, prevention of preeclampsia and cancer, and the promotion of longevity. Am J Obstet Gynecol. 2017; 217(3): 282-302, doi: 10.1016/j.ajog.2017.06.003, indexed in Pubmed: 28619690.

16. Kumar R, Lowe J, Thompson-Hutchison F, et al. Implementation and Evaluation of the "Metformin First" Protocol for Management of Gestational Diabetes. Can J Diabetes. 2019; 43(8): 554-559, doi: 10.1016/j. jcjd.2019.06.005, indexed in Pubmed: 31562030.

17. Tarry-Adkins JL, Aiken CE, Ozanne SE. Neonatal, infant, and childhood growth following metformin versus insulin treatment for gestational diabetes: A systematic review and meta-analysis. PLoS Med. 2019; 16(8): e1002848, doi: 10.1371/journal.pmed.1002848, indexed in Pubmed: 31386659.

18. Hu G, Bouchard C, Bray GA, et al. Trunk versus extremity adiposity and cardiometabolic risk factors in white and African American adults. Diabetes Care. 2011; 34(6): 1415-1418, doi: 10.2337/dc10-2019, indexed in Pubmed: 21505210.

19. Nanovskaya TN, Nekhayeva IA, Patrikeeva SL, et al. Transfer of metformin across the dually perfused human placental lobule. Am J Obstet Gynecol. 2006; 195(4): 1081-1085, doi: 10.1016/j.ajog.2006.05.047, indexed in Pubmed: 16824464 .

20. Rowan JA, Hague WM, Gao W, et al. MiG Trial Investigators. Metformin versus insulin for the treatment of gestational diabetes. N Engl J Med. 2008; 358(19): 2003-2015, doi: 10.1056/NEJMoa0707193, indexed in Pubmed: 18463376.

21. Rowan JA. MiG Investigators. A trial in progress: gestational diabetes. Treatment with metformin compared with insulin (the Metformin in Gestational Diabetes [MiG] trial). Diabetes Care. 2007; 30 Suppl 2 : S214-S219, doi: 10.2337/dc07-s219, indexed in Pubmed: 17596475.

22. Ijäs $H$, Vääräsmäki $M$, Saarela $T$, et al. A follow-up of a randomised study of metformin and insulin in gestational diabetes mellitus: growth and development of the children at the age of 18 months. BJOG. 2015; 122(7): 994-1000, doi: 10.1111/1471-0528.12964, indexed in Pubmed 25039582.

23. Tertti K, Eskola E, Rönnemaa T, et al. Neurodevelopment of Two-Year-Old Children Exposed to Metformin and Insulin in Gestational Diabetes Mellitus. J Dev Behav Pediatr. 2015; 36(9): 752-757, doi: 10.1097/DBP.0000000000000230, indexed in Pubmed: 26535884

24. Xu Q, Xie Q. Long-term effects of prenatal exposure to metformin on the health of children based on follow-up studies of randomized controlled trials: a systematic review and meta-analysis. Arch Gynecol Obstet. 2019; 299(5): 1295-1303, doi: 10.1007/s00404-019-05124-w, indexed in Pubmed: 30953188

25. Rowan JA, Rush EC, Plank LD, et al. Metformin in gestational diabetes: the offspring follow-up (MiG TOFU): body composition and metabolic outcomes at 7-9 years of age. BMJ Open Diabetes Res Care. 2018; 6(1): e000456, doi: 10.1136/bmjdrc-2017-000456, indexed in Pubmed: 29682291.

26. Diav-Citrin O, Steinmetz-Shoob S, Shechtman S, et al. In-utero exposure to metformin for type 2 diabetes or polycystic ovary syndrome: A prospective comparative observational study. Reprod Toxicol. 2018; 80 85-91, doi: 10.1016/j.reprotox.2018.05.007, indexed in Pubmed: 29857030.

27. Hjorth-Hansen A, Salvesen $\varnothing$, Engen Hanem LG, et al. Fetal Growth and Birth Anthropometrics in Metformin-Exposed Offspring Born to Mothers With PCOS. J Clin Endocrinol Metab. 2018; 103(2): 740-747, doi: 10.1210/jc.2017-01191, indexed in Pubmed: 29165598.

28. Piacquadio K, Hollingsworth DR, Murphy H. Effects of in-utero exposure to oral hypoglycaemic drugs. Lancet. 1991; 338(8771): 866-869, doi: 10.1 016/0140-6736(91)91512-s, indexed in Pubmed: 1681225.

29. Coetzee EJ. Counterpoint: Oral hypoglyemic agents should be used to treat diabetic pregnant women. Diabetes Care. 2007; 30(11): 2980-2982, doi: 10.2337/dc07-1620, indexed in Pubmed: 17965316.

30. Coetzee EJ, Jackson WP. Metformin in management of pregnant insulin-independent diabetics. Diabetologia. 1979; 16(4): 241-245, doi: 10.1007/bf01221950, indexed in Pubmed: 428695.

31. Begum MR, Khanam NN, Quadir E, et al. Prevention of gestational diabetes mellitus by continuing metformin therapy throughout pregnancy in women with polycystic ovary syndrome. J Obstet Gynaeco Res. 2009; 35(2): 282-286, doi: 10.1111/j.1447-0756.2008.00876.x, indexed in Pubmed: 19708174

32. Hanem LG, Stridsklev S, Júlíusson PB, et al. Metformin Use in PCOS Pregnancies Increases the Risk of Offspring Overweight at 4 Years of Age: Follow-Up of Two RCTs. J Clin Endocrinol Metab. 2018; 103(4): 1612-1621, doi: 10.1210/jc.2017-02419, indexed in Pubmed: 29490031.

33. Løvvik TS, Carlsen SM, Salvesen $\varnothing$, et al. Use of metformin to treat pregnant women with polycystic ovary syndrome (PregMet2): a randomised, double-blind, placebo-controlled trial. Lancet Diabetes Endocrinol. 2019; 7(4): 256-266, doi: 10.1016/S2213-8587(19)30002-6, indexed in Pubmed: 30792154

34. Valdés E, Sepúlveda-Martínez A, Candia P, et al. Metformin as a prophylactic treatment of gestational diabetes in pregnant patients with pregestational insulin resistance: A randomized study. J Obstet Gynaecol Res. 2018; 44(1): 81-86, doi: 10.1111/jog.13477, indexed in Pubmed: 29094444. 


\title{
Zastosowanie metforminy w ciąży
}

\author{
Joanna Krupej-Kędzierska ${ }^{1,2}$, Edyta Cichocka' ${ }^{1}$ Leszek Kędzierski ${ }^{3}$, Bogusław Okopieñ ${ }^{2}$, \\ Janusz Gumprecht ${ }^{1}$
}

${ }^{1}$ Katedra i Klinika Chorób Wewnętrznych, Diabetologii i Nefrologii w Zabrzu, Wydział Nauk Medycznych w Zabrzu, Ślaski Uniwersytet Medyczny w Katowicach, Polska

${ }^{2}$ Oddziat Chorób Wewnętrznych i Farmakologii Klinicznej, Śląski Uniwersytet Medyczny w Katowicach, Polska

${ }^{3}$ Oddział Chorób Wewnętrznych i Metabolicznych Katedry Chorób Wewnętrznych, Śląski Uniwersytet Medyczny w Katowicach, Polska

Artykuł jest tłumaczeniem pracy: Joanna Krupej-Kędzierska, Edyta Cichocka, Leszek Kędzierski, Bogusław Okopień, Janusz Gumprecht. Metformin therapy in pregnancy. Endokrynol Pol 2020; 71 (2): 184-189.

Należy cytować wersję pierwotną. Piśmiennictwo dostępne w wersji pierwotnej na stronach 188-189.

\section{Streszczenie}

Cukrzyca ciążowa, czyli zaburzenie metabolizmu węglowodanów występujące w ciąży, należy do najczęstszych powikłań metabolicznych występujących w tym okresie. Za jej przyczynę uważa się dysfunkcję komórek beta trzustki oraz oporność na działanie insuliny, pojawiające się w ciąży. Aktualnie szacuje się, że cukrzyca ciążowa występuje u 1-25\% pacjentek. Jej rozpoznanie i wdrożenie właściwego postępowania pozwala zredukować ryzyko powikłań u noworodków, zmniejszyć współczynnik śmiertelności okołoporodowej oraz poprawić rokowanie zarówno u matki, jak i jej potomstwa. Metformina przyjmowana jest przez wiele pacjentek jeszcze przed ciążą, zarówno z powodu już wcześniej rozpoznanej cukrzycy typu 2, jak i w terapii stanów przedcukrzycowych, otyłości oraz zespołu policystycznych jajników, jako element leczenia insulinooporności. Stosowanie metforminy w ciąży jest postępowaniem budzącym kontrowersje już od wielu lat, zwłaszcza w zakresie bezpieczeństwa kontynuowania tej terapii. Dostępne dane naukowe zwracają uwagę zarówno na korzyści, jak i możliwe negatywne konsekwencje stosowania leku u potomostwa chorych leczonych metforminą. Zagadnienie to dotyczy nie tylko pacjentek z cukrzycą typu 2, ale także z zespołem policystycznych jajników, które to znajdują się w grupie zwiększonego ryzyka poronień, porodu przedwczesnego oraz rozpoznania cukrzycy ciążowej na kolejnych etapach ciąży. Wątpliwości dotyczące mechanizmów działania metforminy, szczególnie na poziomie komórkowym, jak dotąd nie pozwoliły na sformułowanie jednoznacznych i ujednoliconych zaleceń w zakresie stosowania tego leku na każdym z etapów ciąży. W niniejszym podsumowaniu przedstawiono aktualny stan wiedzy dotyczący stosowania metforminy w okresie ciąży. (Endokrynol Pol 2020; 71 (2): 190-195)
\end{abstract}

Słowa kluczowe: metformina; ciąża; cukrzyca ciążowa

\section{Wstęp}

Cukrzyca ciążowa, czyli zaburzenie metabolizmu węglowodanów występujące w ciąży, należy do najczęstszych powikłań metabolicznych w tym okresie [1]. Mianem cukrzycy ciążowej określa się hiperglikemię stwierdzaną po raz pierwszy w ciąży u pacjentek, u których wcześniej nie występowały zaburzenia metabolizmu węglowodanów. Za jej przyczynę uważa się dysfunkcję komórek beta trzustki oraz oporność na działanie insuliny, pojawiające się w ciąży. Predyspozycja do tego zaburzenia istnieje już przed ciążą, a zmiany hormonalne oraz przyrost masy ciała typowy dla ciąży prowadzą do jego ujawnienia [2,3]. Wpływ na ujawnienie się choroby mają również czynniki środowiskowe, przede wszystkim epidemia otyłości, wynikająca ze szkodliwych nawyków żywieniowych, jak i niekorzystnych zmian w zakresie stylu życia obserwowanych na całym świecie [1].

Szacuje się, że około $1 \%$ pacjentek ma cukrzycę w momencie zajścia w ciążę. Cukrzycę ciążową obserwuje się natomiast u 1-25\% pacjentek w zależności od kraju pochodzenia, co wiąże się zarówno z różnymi kryteriami diagnostycznymi, jak i wpływem czynników etnicznych [4-7]. Jej rozpoznanie i wdrożenie właściwego postępowania pozwala zredukować ryzyko powikłań u noworodków, zmniejszyć współczynnik śmiertelności okołoporodowej oraz poprawić rokowanie zarówno u matki, jaki jej potomstwa [8]. Uważa się, że cukrzyca ciążowa u matki jest silnym czynnikiem prognostycznym zaburzeń metabolizmu u dziecka, zarówno w dzieciństwie, jak i dorosłości. 
Aktualnie zgodnie z wytycznymi Światowej Organizacji Zdrowia (2013) przyjętymi w Polsce dokonano podziału hiperglikemii występującej $w$ ciąży na dwie kategorie: cukrzycę w ciąży, czyli nieprawidłowość, która już w momencie stwierdzenia spełnia ogólne kryteria rozpoznania cukrzycy, oraz cukrzycę ciążową, do której ujawnienia się dochodzi najczęściej w okresie drugiego lub trzeciego trymestru ciąży i spełnia ona szczególne kryteria przewidziane dla okresu ciąży. Należy także pamiętać o pacjentkach, które w chwili stwierdzenia ciąży mają już postawione rozpoznanie cukrzycy typu 2 i wdrożoną doustną farmakoterapię, najczęściej z zastosowaniem metforminy.

Z uwagi na mnogość sytuacji klinicznych stosowanie metforminy $w$ ciąży od wielu lat jest postępowaniem budzącym kontrowersje. Lek ten przyjmowany jest przez wiele pacjentek jeszcze przed ciążą zarówno z powodu wcześniej rozpoznanej cukrzycy typu 2, jak i w terapii stanów przedcukrzycowych, otyłości czy też zespołu policystycznych jajników (PCOS, polycystic ovary syndrome), jako element leczenia insulinooporności [9]. Ponadto w wielu krajach możliwe jest stosowanie tego leku jako jednej z opcji terapeutycznych cukrzycy ciążowej, a postępowanie to często jest uwarunkowane czynnikami ekonomicznymi. Należy więc ustalić, czy bezpieczne jest kontynuowanie terapii metforminą u tych pacjentek, u których lek ten stosowano w okresie okołokoncepcyjnym, a jeśli tak, to jak długo można go bezpiecznie stosować, aby nie narazić rozwijającego się płodu na jego potencjalnie niekorzystne działanie. Ten aspekt zagadnienia dotyczy nie tylko pacjentek z cukrzycą typu 2, ale także chorych z PCOS, które znajdują się $\mathrm{w}$ grupie zwiększonego ryzyka poronień, porodu przedwczesnego oraz rozpoznania cukrzycy ciążowej na kolejnych etapach ciąży [6].

Dane naukowe z przeprowadzonych badań klinicznych oraz badań ankietowych u chorych stosujących w ciąży metforminę zwracają uwagą na większy poziom zadowolenia ze stosowanej terapii, mniejsze natężenie stresu związane $\mathrm{z}$ rozpoznaniem oraz $\mathrm{w}$ wielu przypadkach równie dobre wyrównanie glikemii jak $w$ grupach chorych stosujących insulinoterapię jako jedyną opcję terapeutyczną [10]. Należy jednak pamiętać, iż w grupie chorych, u których istnieje podejrzenie niewydolności łożyskowej, nadciśnienia tętniczego, stanu przedrzucawkowego lub ograniczenia wzrostu płodu, metforminy nie powinno się rozważać jako opcji terapeutycznej [11]. Ponadto analiza danych naukowych wskazuje, że pacjentki otyłe, z wyższą glikemią na czczo, będą i tak wymagały zastosowania insulinoterapii, więc należą one do grupy chorych, która odniesie potencjalnie mniej korzyści ze stosowania tego leku [12]. W związku z tym w wielu przypadkach, w miarę postępu ciąży, zastosowanie tego leku nie jest ostatecznym rozwiązaniem i zachodzi konieczność wdrożenia insulinoterapii, gdyż istnieje ryzyko, że chore będą uzyskiwały gorsze wyrównanie niż pacjentki stosujące insulinę jako pierwszą interwencję farmakologiczną [12].

Kolejnym ważnym aspektem terapii doustnej metforminą kontynuowanej lub dopiero wdrożonej jest okres ciąży, w którym stosowanie metforminy jest całkowicie bezpieczne dla płodu. Szczególny niepokój budzi pierwszy trymestr ciąży, który jest okresem intensywnej organogenezy. W krajach, w których dopuszczono ten lek do stosowania w ciąży, zaleca się stosowanie go w drugim i trzecim trymestrze. Taki postępowanie uznaje się za bezpieczniejsze z uwagi na nadal zbyt małą liczbę danych dotyczących jej potencjalnie teratogennego działania $\mathrm{w}$ pierwszym trymestrze ciąży [4].

Nieprawidłowe wyrównanie glikemii jest obarczone poważnymi powikłaniami położniczymi, do których należą urodzenie dziecka o dużej masie ciała, poród przedwczesny, poród zakończony cięciem cesarskim, wystąpienie wad wrodzonych, stanu przedrzucawkowego, hipoglikemii u noworodka, zwiększonego ryzyka poronienia na wczesnych etapach ciąży [5]. Z tego powodu tak ważne jest prawidłowe przygotowanie do ciąży w okresie prekoncepcyjnym, osiągnięcie zalecanych kryteriów wyrównania glikemii u pacjentek z wcześniej rozpoznaną cukrzycą, normalizacja masy ciała oraz identyfikowanie grup kobiet, u których istnieje większe ryzyko wystąpienia cukrzycy ciążowej, zarówno na początku ciąży, jak i w drugim i trzecim trymestrze jej trwania $[5,13,14]$.

\section{Postępowanie w cukrzycy ciążowej}

W 1970 roku Coetzee i Jackson po raz pierwszy opisali zastosowanie metforminy w ciąży [15]. Od tego czasu wielu autorów podkreślało istotne korzyści z zastosowania doustnej farmakoterapii $w$ tym okresie, polegające na poprawie wspólpracy z pacjentką, szybszym uzyskaniu prawidłowego wyrównania glikemii, a także redukcji kosztów farmakoterapii. Zastosowanie terapii doustnej eliminuje strach przed iniekcjami insuliny, hipoglikemią, a także niekontrolowanym przyrostem masy ciała w ciąży $[1,5]$.

W 2019 roku Kumar i wsp. zaprezentowali wyniki badania ankietowego Metformin first, do którego włączono pacjentki z cukrzycą ciążową, które miały możliwość (po uprzednim poinformowaniu ich o możliwych działaniach niepożądanych terapii) wyboru preferowanej opcji terapeutycznej. Było to badanie ankietowe, obejmujące chore będące w ciąży w 2015 i 2016 roku. Na podstawie zebranych danych nie wykazano zwiększonego ryzyka wad wrodzonych i powikłań położniczych 
dla matki i płodu. Zwracało uwagę natomiast zadowalające wyrównanie glikemii, skuteczność leczenia oraz większa satysfakcja z leczenia w grupie pacjentek, u których stosowano metforminę [16].

Celami leczenia cukrzycy ciążowej jest zapobieganie makrosomii płodu oraz jej późniejszym konsekwencjom, zapobieganie powikłaniom okołoporodowym, a w przyszłości zredukowanie ryzyka rozwoju powikłań sercowo-naczyniowych u dzieci matek, u których wystąpiła cukrzyca ciążowa. W 2019 roku Adkinsa i wsp. przeprowadzili metaanalizę badań uzyskanych $\mathrm{z}$ baz danych medycznych (PubMed). Z oceny wykluczono badania, w których cukrzyca występowała przed ciążą oraz te, w których liczebność grup była mniejsza niż 50 uczestników, wykluczono również przypadki ciąż mnogich. W analizie wykazano, że w okresie ciąży płody matek leczonych metforminą mają mniejszą masę ciała, a noworodki rodzą się z mniejszą masą urodzeniową, ale w późniejszych latach życia dzieci te mają średnią masę ciała większą od dzieci matek leczonych w ciąży insuliną, co w świetle danych naukowych stanowi czynnik ryzyka chorób układu sercowo-naczyniowego w dorosłym życiu [17]. Ponadto u dzieci, których matki leczono metforminą, w 2. roku życia obserwowano zwiększoną objętość tkanki tłuszczowej trzewnej i brzusznej oraz większy wskaźnik masy ciała (BMI, body mass index) przy braku różnic w długości ciała [17]. Z kolei obserwacje w 5. roku życia wskazują na większą wartość BMI, co według badaczy może być konsekwencją zwiększonego magazynowania tkanki tłuszczowej brzusznej $[17,18]$.

\section{Przegląd wybranych aktualnych badań i metaanaliz dotyczących zastosowania metforminy w ciąży}

Metformina działa na tkanki obwodowe, zwiększając ich wrażliwość na insulinę oraz zmniejsza wątrobową glukoneogenezę. Wykazuje także wiele innych działań, do których należy modulacja ekspresji genów, efekty przeciwnowotworowe oraz działanie przeciwzapalne wyrażone poprzez hamowanie produkcji cytokin prozapalnych i zmniejszenie różnicowania monocytów w kierunku makrofagów [6]. Jej działanie wiąże się ze zmniejszeniem transportu elektronów w mitochondriach wątroby, co skutkuje redukcją w zakresie glukoneogenezy i lipogenezy.

Metformina, w przeciwieństwie do insuliny, przekracza barierę łożyskową [19]. Jej stężenie we krwi płodu jest porównywalne ze stężeniem we krwi matki. Może to skutkować efektami wyrażonymi na poziomie komórkowym - przez to zmieniać metabolizm komórek na wczesnych etapach wzrostu i różnicowania [6]. Wpływ ten obejmuje zarówno tkanki płodu, jak i tkanki łożyska. Z uwagi na ograniczoną liczbę danych klinicznych efekty te są trudne do przewidzenia, także w obserwacji długofalowej [6]. Transport metforminy zachodzi przez obecne w łożysku transportery OTC-3 charakterystyczne dla okresu ciąży [6]. Zależy on od okresu ciąży oraz budowy i wydolności łożyska. Istnieje także możliwość kumulacji leku w obrębie tkanek łożyska, przez co jego wpływ na metabolizm komórek jest trudniejszy do przewidzenia, a potencjalny efekt działania może wydłużać się w czasie [6]

Przedostawanie się metforminy do krwi płodu na wczesnych etapach embriogenezy może wpłynąć teratogennie, jednak wyniki przeprowadzonych dotychczas badań naukowych nie potwierdziły tego działania. Na wczesnych etapach ciąży mechanizmy oddychania tlenowego nie odgrywają tak dużej roli w procesie wzrostu i różnicowania komórek z uwagi na niewielką liczbę mitochondriów i dominujący metabolizm beztlenowy w tym okresie. Ta zależność zmienia się na kolejnych etapach ciąży, kiedy na poziomie komórkowym dominują mechanizmy tlenowego oddychania $\mathrm{w}$ mitochondriach, a te mogą być blokowane przez dostarczoną metforminę. Ponadto poprzez aktywację AMP-kinazy hamuje ona mechanizmy proliferacji, syntezy białek oraz nasila apoptozę w komórkach. Sugeruje się także jej możliwe działanie epigenetyczne, co może wywoływać skutki metaboliczne w kolejnych latach życia [11].

W przeprowadzonym przez Bao i wsp. w 2019 roku badaniu, uwzględniającym rejestr z 11 krajów europejskich, nie wykazano zwiększonego ryzyka wad wrodzonych u dzieci, których matki stosowały metforminę w pierwszym trymestrze ciąży. Jednakże, poza potencjalnym efektem teratogennym, nie można także zapominać o możliwych konsekwencjach stosowania tego leku przez matkę w ciąży w kolejnych latach życia dziecka [5].

Metaanaliza randomizowanych badań kontrolnych zebranych na podstawie baz medycznych (PubMed, Embase, Cochrane Library) uwzględniała następstwa stosowania metforminy $\mathrm{u}$ kobiet $\mathrm{w}$ ciąży dla płodu i dzieci w kolejnych latach życia. Z badania wyłączono pacjentki z cukrzycą rozpoznaną przed ciążą. Chore stosowały metforminę, metforminę $\mathrm{w}$ połączeniu $\mathrm{z}$ insuliną oraz insulinę. Ostatecznie do metaanalizy włączono 24 badania, w tym 17 badań randomizowanych. W odniesieniu do noworodków oceniano masę urodzeniową, występowanie makrosomii, występowanie hipoglikemii w okresie noworodkowym, konieczność interwencji anestezjologicznej, liczbę punktów w skali Apgar < 7 w 5. min. życia, hiperbilirubinemię, zespół niewydolności oddechowej, obecność wad wrodzonych oraz $\mathrm{pH}$ krwi pępowinowej. W przypadku matki oceniano wiek pacjentki w chwili porodu, obecność nad- 
ciśnienia indukowanego ciążą, liczbę cesarskich cięć, przyrost masy ciała oraz ocenę wyrównania glikemii $\left(\mathrm{HbA}_{1 \mathrm{c}} \%\right)$ [5]. Do oceny czasu trwania ciąży i wieku matki $w$ chwili porodu włączono 847 pacjentki. Ta część analizy wykazała iż, zastosowanie metforminy może skrócić ciążę i wywołać wystąpienie przedwczesnego porodu [5]. Nie rejestrowano różnic w zakresie odsetka cesarskich cięć. Zaobserwowano natomiast, że w grupie pacjentek stosujących metforminę całkowity przyrost masy ciała był mniejszy w porównaniu z grupą, w której pacjentki otrzymywały insulinę [5].

Z kolei w odniesieniu do niemowląt stwierdzono, iż ich urodzeniowa masa ciała była mniejsza w grupie, w której kobiety leczono metforminą. Wykazano ponadto, iż leczenie doustne nieznacznie zmniejszało ryzyko makrosomii płodu. Dodatkowo u dzieci matek stosujących metforminę ryzyko hipoglikemii po porodzie było mniejsze, mniejsza była u nich także liczba interwencji anestezjologicznych [5]. Najbardziej istotnym czynnikiem, który wpływał na wystąpienie powikłań położniczych, było niezadowalające wyrównanie glikemii $\mathrm{w}$ okresie poprzedzającym ciążę oraz w pierwszym trymestrze ciąży.

Ocenę efektów stosowania metforminy u kobiet w ciąży w kolejnych latach życia potomstwa przeprowadzono na podstawie pięciu randomizowanych badań klinicznych. W pracy Rowan i wsp. wykazano, iż nie ma różnicy pomiędzy grupami pacjentek stosujących metforminę $\mathrm{i}$ insulinę $\mathrm{w}$ aspekcie gromadzenia tkanki tłuszczowej zlokalizowanej centralnie, ale stwierdzono, że dzieci matek przyjmujących metforminę charakteryzują się większym gromadzeniem podskórnej tkanki tłuszczowej w drugim roku życia, co sugeruje, że pod wpływem metforminy dochodzi u nich do promowania tkanki tłuszczowej podskórnej, a w mniejszym stopniu trzewnej $[20,21]$. Zaobserwowano, że w 12. i 18. miesiącu życia masa ciała tych dzieci była istotnie większa, a w 18. miesiącu życia były one dłuższe niż dzieci matek leczonych insuliną [12]. Nie zauważono natomiast różnicy w rozwoju społecznym, aktywności językowej oraz motorycznej [21]. Podobnej obserwacji dokonała Tertti i wsp., jednak w badaniu wykazano, że dzieci, których matki stosowały w ciąży metforminę, charakteryzowały się uboższymi zdolnościami językowymi [23, 24].

Dalsza obserwacja przeprowadzona przez Rowan i wsp. dotyczyła dzieci od 7. do 9. roku życia — wykazano, że dzieci w grupie poddanej działaniu metforminy były większe niż dzieci matek leczonych insuliną [25].

W kolejnej metaanalizie Bao i wsp. podkreślili korzyści z wprowadzonej terapii doustnej wynikające z istotnej redukcji glikemii poposiłkowej, wcześniejszego uzyskania celów terapeutycznych i mniejszego przyrostu masy ciała w grupach stosujących metformi- nę. Oczywiście nie bez znaczenia jest wyjściowa masa ciała oraz zmiana w zakresie stylu życia pacjentek. Natomiast $\mathrm{w}$ zakresie powikłań u noworodków podkreśla się fakt redukcji ryzyka hipoglikemii poporodowej $\mathrm{i}-\mathrm{w}$ konsekwencji-towarzyszącego jej uszkodzenia mózgu [5].

W 2015 roku Ainudi i wsp. przeprowadzili badania w grupie kobiet pochodzących z Pakistanu i Południowej Azji, dotyczące stosowania w ciąży metforminy $\mathrm{w}$ monoterapii, metforminy $\mathrm{w}$ połączeniu $\mathrm{z}$ insuliną lub samej insuliny. W badaniu wykazano, iż u pacjentek otrzymujących metforminę oraz metforminę z insuliną przyrost masy ciała był mniejszy niż u pacjentek otrzymujących insulinę. W grupach stosujących metforminę było także więcej porodów siłami natury niż w grupie stosującej insulinę [8].

Zastosowanie metforminy w cukrzycy ciążowej było także oceniane w badaniu Metformin in Gestational Diabetes Trial (MiG), w którym wzięło udział 751 kobiet, przydzielonych do dwóch grup: przyjmujących metforminę oraz stosujących insulinoterapię. $W$ grupie stosującej metforminę 46,3\% pacjentek wymagało dodatkowo insulinoterapii $\mathrm{w}$ celu poprawy kontroli glikemii. W grupie chorych stosujących metforminę stwierdzono więcej porodów przed terminem przy mniejszym ryzyku hipoglikemii u noworodków niż wśród pacjentek leczonych insuliną. Kontynuacją obserwacji było badanie MiG TOFU, w którym dzieci matek uczestniczących w badaniu MiG objęto długoterminową oceną w 2., 4. i 9. roku życia. W 2. roku życia dzieci obwód przedramienia oraz fałd skórny w okolicy łopatki i mięśnia dwugłowego były większe niż analogiczne wymiary u dzieci, których matki stosowały insulinę. U dzieci w 9. roku życia stwierdzono, iż BMI, obwód ramienia, przedramienia, talii oraz fałdu skórnego w okolicy łopatki i mięśnia dwugłowego także były większe w grupie dzieci których matki były leczone metforminą [12, 25].

Z dostępnych danych naukowych wynika, że wpływ metforminy na tkanki płodu w pierwszym trymestrze ciąży może być niewielki z uwagi na ograniczoną liczbę transporterów OCT na początku ciąży w tkankach płodowych, jednakże dane dotyczące stosowania tego leku w pierwszym trymestrze ciąży są ograniczone [26]. W tym okresie rozwoju płodu procesy oddychania tlenowego $\mathrm{w}$ mitochondriach odgrywają mniejszą rolę, a jego znaczenie zaczyna wzrastać dopiero w drugim i trzecim trymetrze ciąży $[6,10]$. Istnieją hipotezy, że metformina może wpływać w większym stopniu na tkanki łożyska, modyfikując transport substancji odżywczych niezbędnych do wzrostu i różnicowania, może także wpływać na rozwój samego łożyska i przez to pośrednio modulować wzrost płodu. Dostępne doniesienia dotyczą 
głównie pacjentek, u których stosowano lek przed ciążą jako terapię wspomagającą leczenie niepłodności w PCOS i jednocześnie leku nie odstawiono na początku ciąży [10].

W badaniu Citrin i wsp. oceniano wpływ metforminy na płód $\mathrm{w}$ pierwszym trymetrze ciąży - do badania włączono pacjentki z cukrzycą typu 2 oraz zespołem policystycznych jajników, u których stosowano metforminę co najmniej przez pierwszy trymetr ciąży. Grupę kontrolną stanowiły pacjentki, u których stosowano insulinę od początku ciąży. Chore włączone do grupy leczonej metforminą były starsze, miały wyższy wskaźnik BMI oraz więcej niepowodzeń położniczych w wywiadzie [26]. Nie wykazano negatywnego wpływu leku na zwiększenie ryzyka wad wrodzonych oraz powikłań położniczych. Nieprawidłowości obserwowane $\mathrm{w}$ badaniu wiązały się głównie ze złym wyrównaniem cukrzycy we wszystkich badanych grupach [26].

Kobiety z zespołem policystycznych jajników obarczone są większym ryzykiem powikłań położniczych, takich jak poronienia, stan przedrzucawkowy czy cukrzyca ciążowa [27].

W badaniach prowadzonych w 1991 roku przez Piacquadio i wsp. w grupie pacjentek z cukrzycą typu 2, u których stosowano metforminę przed ciążą i kontynuowano terapię w pierwszym trymestrze, stwierdzono występowanie wad wrodzonych u dzieci, jednakże liczebność ocenianych grup była mała. Ponadto na uzyskane wyniki mogły wpływać prawdopodobna duża liczba przypadków nieleczonej cukrzycy przed ciążą i jej złe wyrównanie w tej grupie chorych [10, 28-30]. W badaniu Begum i wsp. przeprowadzonym w 2013 roku, w którym metforminę stosowano na początku ciąży (lek odstawiono po pozytywnym wyniku testu ciążowego), u pacjentek z PCOS nie stwierdzono wad wrodzonych u potomstwa [31].

Stosunkowo niewielka liczebność zarówno grup badanych, jak i grup kontrolnych stanowią istotne ograniczenie wszystkich cytowanych badań. Ponadto w wielu próbach zaprzestawano stosowania metforminy po stwierdzeniu ciąży lub przed końcem pierwszego trymestru, więc uzyskane wyniki mogą nie być jednoznaczne.

W opublikowanych w 2010 roku wynikach prospektywnego, randomizowanego badania kontrolnego PregMet u pacjentek z PCOS, stosujących metforminę, zarówno u płodów w 32. tygodniu ciąży, jak i u noworodków po urodzeniu stwierdzono zwiększony obwód głowy. Obserwacja ta dotyczyła jednak dzieci urodzonych przez kobiety otyłe lub z nadwagą już w okresie poprzedzającym ciążę [32]. Co więcej, obwód głowy dziecka był korzystnym czynnikiem wpływającym na poprawę funkcji poznawczych oraz rokowania w za- kresie chorób sercowo-naczyniowych [32]. Dzieci matek bez nadwagi i otyłości miały mniejszą długość i masę ciała po urodzeniu niż dzieci w grupie kontrolnej [32]. Wykazano także, iż dzieci pacjentek z PCOS otrzymujących placebo miały mniejszą długość ciała przy typowej średniej masie ciała, co może wskazywać na hamujący wpływ samego PCOS na wzrost [32]. Dalsza obserwacja wykazała, że u dzieci tych w 4. roku życia wskaźnik BMI był wyższy, a tendencja do nadwagi i otyłości większa niż u dzieci z grup kontrolnych [6, 32].

Warto też wspomnieć, że zastosowanie metforminy przed ciążą oraz przez cały okres ciąży u kobiet z PCOS może stanowić czynnik ochronny, szczególnie przed późnymi powikłaniami położniczymi, takimi jak poronienie po 13. tygodniu ciąży i poród przedwczesny. W 2019 roku opublikowano wyniki badania PregMet2, w którym brały udział pacjentki z PCOS, stosujące metforminę (lub placebo) z przyczyn położniczych w okresie okołokoncepcyjnym, a następnie od początku ciąży, natomiast do drugiej grupy należały chore, $\mathrm{u}$ których nie stosowano interwencji farmakologicznej. W badaniu wykazano, iż w grupie przyjmującej metforminę występował mniejszy przybór masy niż u kobiet przyjmujących placebo. Nie rejestrowano różnic w zakresie masy ciała noworodków, natomiast obserwowano większy obwód głowy $\mathrm{u}$ dzieci matek stosujących metforminę, podobnie jak w obserwacji PregMet. W badaniu nie stwierdzono istotnej statystycznie różnicy w występowaniu porodu przedwczesnego oraz późnych epizodów poronienia (po 13. tygodniu ciąży). Nie stwierdzono także wpływu metforminy na rozwój cukrzycy ciążowej oraz na późniejsze interwencje terapeutyczne u tych pacjentek $[33,34]$. Pomimo przeprowadzenia kilku metaanaliz dotyczących tego zagadnienia nie uzyskano jednoznacznych wyników odnośnie protekcyjnego działania metforminy w zakresie poronień oraz nie udowodniono, aby odstawienie leku na początku ciąży zwiększało ryzyko poronienia [6].

Na przestrzeni ostatnich lat podejmowano także próby zastosowania metforminy w prewencji cukrzycy ciążowej u pacjentek z PCOS oraz otyłością występującą przed ciążą. Metaanaliza badań z lat 2012-2018 przeprowadzona przez Doi i wsp. w 2019 roku nie potwierdziła prewencyjnego działania metforminy w tych grupach [2].

Istotną wadą badań klinicznych dotyczących stosowania metforminy w ciąży jest fakt, iż obejmują one małe grupy pacjentek, a interwencje farmakologiczne są często przerywane w kolejnych miesiącach ciąży, co stanowi czynnik istotnie ograniczający te obserwacje oraz uniemożliwiający jednoznaczne podsumowanie i wysunięcie definitywnych wniosków. Należy też pamiętać, że w wielu przypadkach u badanych pacjentek 
cukrzyca typu 2 występowała już przed ciążą i nie była ona prawidłowo wyrównana, a więc stwierdzone przypadki wad wrodzonych mogą być konsekwencją ekspozycji na hiperglikemię a nie wynikiem stosowania metforminy na wczesnych etapach ciąży [10].

\section{Podsumowanie}

Pomimo wielu badań oraz metaanaliz dotyczących stosowania metforminy w ciąży, PCOS przebiegającym z insulinoopornością oraz jako kontynuacji terapii cukrzycy typu 2, nadal wiele pytań pozostaje bez odpowiedzi. Wątpliwości dotyczące mechanizmów działania metforminy, szczególnie na poziomie komórkowym, w tej grupie chorych, jak dotąd nie pozwoliły na sformułowanie jednoznacznych i ujednoliconych zaleceń w zakresie stosowania tego leku na każdym z etapów ciąży [25]. Nie ulega wątpliwości, że głębszej analizy wymagają możliwe długofalowe konsekwencje stosowania tego leku w ciąży. Aktualnie obserwacje te są zbyt krótkie i dotyczą zbyt małych grup pacjentek. Niepokojące są doniesienia o zwiększonym wskaźniku BMI oraz zwiększonej masie ciała we wczesnym dzieciństwie u dzieci matek stosujących metforminę, co może w konsekwencji wpływać na wzrost ryzyka sercowo-naczyniowego nie tylko w okresie dorosłości, ale już w dzieciństwie. Należy także pamiętać, iż za dobrostan płodu w okresie ciąży, a także za rokowanie w kolejnych latach życia, odpowiada wiele czynników związanych ze stylem życia matki, masą ciała przed ciążą oraz jej przyrostem w ciąży.

Aktualne wytyczne Polskiego Towarzystwa Diabetologicznego dotyczące leczenia cukrzycy ciążowej jednoznacznie zalecają rozpoczęcie insulinoterapii w przypadku, gdy modyfikacje diety i stylu życia przestają być skuteczne, oraz u pacjentek leczonych przed ciążą doustnymi lekami przeciwcukrzycowymi. Uzasadnieniem dla tego stanowiska jest właśnie niejednoznaczny stan wiedzy w zakresie wpływu metforminy na profil metaboliczny i możliwe modyfikacje na poziomie epigenetycznym, czego skutkiem mogą być trwałe niekorzystne zmiany u potomstwa kobiet z cukrzycą ciążową [14].

\section{Konflikt interesów}

Autorzy nie zgłaszają konfliktu interesów. 